\title{
Soil Microbial Dynamics and Enzyme activities as Influenced by Organic Nutrient Management in Sunflower (Helianthus annuus L.)
}

\author{
M. Chaithra and G. M. Sujith*
}

Department of Agronomy, University of Agricultural Sciences, GKVK, Bangalore, India

*Corresponding author

\section{A B S T R A C T}

\begin{tabular}{l} 
K e y w o r d s \\
$\begin{array}{l}\text { FYM, Jeevamrutha, } \\
\text { Dehydrogenase, } \\
\text { Sunflower, Oil } \\
\text { content, Microbes }\end{array}$ \\
Article Info \\
$\begin{array}{l}\text { Accepted: } \\
\text { 10 July } 2020 \\
\text { Available Online: } \\
\text { 10August } 2020\end{array}$ \\
\hline
\end{tabular}

A field experiment was conducted at Zonal Agricultural Research Station, University of Agricultural Sciences, Gandhi Krishi Vignana Kendra, Bangalore during 2017 to study the effect of nutrient management practices through organics on soil biological properties of sunflower grown on alfisols of eastern dry zone of Karnataka. There were nine treatment combinations laid out in factorial randomized complete block design and replicated thrice. Among different treatment combinations application of FYM at 150 per cent $\mathrm{N}$ equivalent and jeevamrutha at $1500 \mathrm{~L} \mathrm{ha}^{-1}$ recorded significantly higher bacterial, fungal, actinomycetes, P-solubilizer and $\mathrm{N}$-fixer population at harvest of sunflower $\left(37.67 \times 10^{6}\right.$,

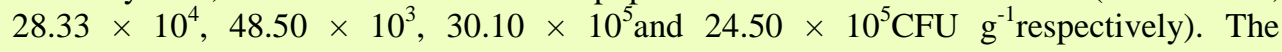
dehydrogenase activity was also examined at peak flowering stage of crop growth and it was found to be higher with application of FYM at 150 per cent $\mathrm{N}$ equivalent and jeevamrutha at $1500 \mathrm{l} \mathrm{ha}^{-1}(50.11 \mu \mathrm{g}$ TPF formed/ $\mathrm{g}$ of soil/ day). Seed yield and oil content of Sunflower were found higher at increased level of FYM and jeevamrutha application.

\section{Introduction}

With increasing population and shrinking resource base, our future need is to increase the agricultural production on a sustainable basis without degrading the resource base. Due to tropical climate, higher temperature has reduced the organic carbon content of the soil as a result microbial activity is also limited to certain extent. So there is a need of use of combined organic sources of nutrients, which help to maintain the healthy crop growth, improve the soil properties and helps to obtain sustainable yield and quality. To achieve all these objectives organic farming serves as a tool to improve the physical, chemical and biological properties of soil and maintains the ecological balance as well as productivity of life supporting systems for the future generations on sustainable basis. Organic production relies on microbially derived ecosystem functions including decomposition, mineralization of plant available nutrients, and nutrient retention and thus, may be a model system for ecological intensification of agriculture (Jackson et al., 2012).

Organic matter serves as a nutrient source (carbon) and energy for diverse soil flora and 
fauna. For mineralization of organic matter, soil fauna and microorganisms have indispensible role to play and they improves the availability of nutrients to the plants. Use of organic liquid products such as beejamrutha, jeevamrutha and panchagavya results in improving the soil physico-chemical and biological properties apart from better growth, yield and quality of crops as they contain macro nutrients, essential micro nutrients, many vitamins, essential amino acids, growth promoting factors like IAA, GA and beneficial microorganisms (Devakumar $e t$ al., 2008 and Tharmaraj et al., 2011).

Sunflower (Helianthus annuus L.) is a major oilseed crop and has gained importance because of its wider adaptability to different agro-climatic regions and cropping pattern, shorter duration, photo insensitiveness and excellent oil quality. Although crop has the yield potential of 2.3 to 2.5 tonnes $\mathrm{ha}^{-1}$ under favourable conditions, but the average productivity is only $0.79 \mathrm{t} \mathrm{ha}^{-1}$. The crop yield can be stabilized and maintained on sustainable manner on long run with the use of organics. With this background, the present experimentation was carried out to study the biological properties of the soil as influenced by the conjunctive use of organic sources farmyard manure and jeevamrutha in Sunflower under irrigated conditions on alfisols of eastern dry zone of Karnataka state.

\section{Materials and Methods}

A field experiment was carried out during kharif2017 at Zonal Agricultural Research Station, University of Agricultural Sciences, Gandhi Krishi Vignana Kendra, Bengaluru. Soil of the experimental site was red sandy loam classified as Alfisols. Organic carbon, available nitrogen, phosphorus and potassium content of the soil were medium $(0.58 \%, 329$ $\mathrm{kg} \mathrm{ha}{ }^{-1}, 44 \mathrm{~kg} \mathrm{ha}^{-1}$ and $214 \mathrm{~kg} \mathrm{ha}{ }^{-1}$ respectively.). The experiment was laid out in factorial randomized complete block design (FRCBD) having farm yard manure and jeevamrutha as two factors and tried each at three levels leading to nine treatment combinations which were replicated thrice. FYM was applied three weeks before sowing and jeevamrutha was applied as soil application at 20, 40, 60 and 80 days after sowing.

Jeevamrutha preparation and application: Jeevamrutha was prepared by mixing $10 \mathrm{~kg}$ cow dung, 10 litre cow urine, $2 \mathrm{~kg}$ local jaggery, $2 \mathrm{~kg}$ pigeon pea flour and hand full of soil. All these were put in 200 litre capacity drum and mixed thoroughly and volume was made up to 200 litre. The mixture was stirred well in clock wise direction and kept in shade covered with wet jute bag. The solution was regularly stirred clockwise in the morning, afternoon and in the evening continuously for 10 days and it was then used for soil application. Jeevamrutha was applied when the soil was wet near the root zone of the crop.

Nutrient composition of FYM was $0.49 \% \mathrm{~N}$, $0.25 \% \mathrm{P}_{2} \mathrm{O}_{5}$ and $0.51 \% \mathrm{~K}_{2} \mathrm{O}$ and the nutrient composition of jeevamrutha was found to be $725 \mathrm{ppm}, 175 \mathrm{ppm}$ and $135 \mathrm{ppm}$ of total nitrogen, phosphorus and potassium respectively. The initial soil microbial population -bacteria, fungi, actinomycetes, $\mathrm{P}$ solubilizer and $\mathrm{N}$-fixer (Soil extract agar, Martin'rose Bengal agar, Kusters agar, Pikovaskaya's and Jensen agar media respectively) in experimental were analysed with the serial dilution plate count technique and as per the procedure outlined (Allen, 1959).

Sunflower hybrid KBSH-53 which is moderately resistant to powdery mildew was used for the field experiment. Sunflower crop was sown on $1^{\text {st }}$ October 2017 with seed rate of $5 \mathrm{~kg} \mathrm{ha}^{-1}$ and seeds were sown at spacing 
of $60 \mathrm{~cm}$ and seed to seed spacing of $30 \mathrm{~cm}$ $(60 \mathrm{~cm} \mathrm{X} 30 \mathrm{~cm})$. Irrigation was provided at 10-15 days interval depending on the stage of crop and soil condition. Necessary aftercare operations were followed as per the recommendations. No major pest and disease incidences were noticed during crop growth. Observations on growth parameters were recorded at regular intervals viz., 30 and 60 days after sowing and at harvest. Experimental data collected was subjected to statistical analysis by adopting Fisher's method of Analysis of Variance (ANOVA) as outlined by Gomez and Gomez (1984). Critical Difference (CD) values were calculated whenever the ' $F$ ' test was found significant at 5 per cent level.

\section{Results and Discussion}

As evident from the table 1 and 2, increase in microbial population viz. bacteria, fungi, actinomycetes, $\mathrm{P}$-solubilizer and $\mathrm{N}$-fixer was observed with increase in the nitrogen equivalent dose of FYM and higher rates of jeevamrutha application.

\section{Microbial Population}

In the present study, among the different levels of FYM, significantly higher bacterial, fungal and actinomycetes population $(30.65 \times$ $10^{6}, 20.41 \times 10^{4}$ and $39.00 \times 10^{3} \mathrm{CFU} \mathrm{g}^{-1}$, respectively)was recorded with FYM at 150 per cent $\mathrm{N}$-equivalent and whereas significantly lower bacterial, fungal and actinomycetes population $\left(23.57 \times 10^{6}, 13.57\right.$ $\times 10^{4}$ and $26.60 \times 10^{4} \mathrm{CFU} \mathrm{g}^{-1}$ respectively) was observed with FYM at 100 per cent Nequivalent (Table 1).

Among the different levels of jeevamrutha, application of jeevamrutha at $1500 \mathrm{~L} \mathrm{ha}^{-1}$ was recorded significantly higher bacterial, fungal and actinomycetes $\left(31.18 \times 10^{6}, 20.07 \times 10^{4}\right.$ and $39.84 \times 10^{3} \mathrm{CFU} \mathrm{g}^{-1}$ respectively) and significantly lower bacterial, fungal, actinomycetes population $\left(21.76 \times 10^{6}, 16.76\right.$ $\times 10^{4}$ and $23.00 \times 10^{4}, \mathrm{CFU} \mathrm{g}{ }^{-1}$ respectively) was recorded with no jeevamrutha application (Table.1).

Among the interaction effects, significantly higher bacterial, fungal and actinomycetes $\left(37.67 \times 10^{6}, 28.33 \times 10^{4}\right.$ and $39.00 \times 10^{3}$ CFU g ${ }^{-1}$ respectively) was recorded with FYM at 150 per cent $\mathrm{N}$ equivalent and jeevamrutha at $1500 \mathrm{~L} \mathrm{ha}^{-1}$ and significantly lower bacterial, fungal and actinomycetes population was recorded with FYM at 100 per cent $\mathrm{N}$ equivalent and without jeevamrutha application $\left(20.77 \times 10^{6}, 10.89 \times 10^{4}\right.$ and $22.09 \times 10^{3}, \mathrm{CFU} \mathrm{g}^{-1}$ respectively) (Table 1 ).

Similarly, among the different levels of FYM, significantly higher $\mathrm{P}$-solubilizer and $\mathrm{N}$-fixers population $\left(27.85 \times 10^{5}\right.$ and $21.67 \times 10^{5} \mathrm{CFU}$ $\mathrm{g}^{-1}$ respectively) was recorded with FYM at 150 per cent $\mathrm{N}$-equivalent and application of jeevamrutha at $1500 \mathrm{~L} \mathrm{ha}^{-1}$ was recorded significantly higher $\mathrm{P}$-solubilizer and $\mathrm{N}$-fixers $\left(28.44 \times 10^{5}\right.$ and $22.10 \times 10^{5} \mathrm{CFU} \mathrm{g^{-1 }}$ respectively) when compared to FYM at 100 per cent $\mathrm{N}$-equivalent and with no jeevamrutha application (Table.2). Among the interaction effects, significantly higher $\mathrm{P}$ solubilizer and $\mathrm{N}$-fixer $\left(8.20 \times 10^{5}\right.$ and $5.48 \times$ $10^{5} \mathrm{CFU} \mathrm{g}^{-1}$ respectively) was recorded with FYM at 150 per cent $\mathrm{N}$ equivalent and jeevamrutha at $1500 \mathrm{~L} \mathrm{ha}^{-1}$ and significantly lower P-solubilizer and $\mathrm{N}$-fixers population was recorded with FYM at 100 per cent $\mathrm{N}$ equivalent and without jeevamrutha application $\left(18.21 \times 10^{5}\right.$ and $15.48 \times 10^{5} \mathrm{CFU}$ $\mathrm{g}^{-1}$ respectively) (Table 2).

Increased microbial population is an indicator of soil fertility and soil health. In the present study, application of FYM and jeevamrutha at different levels significantly influenced the bacteria, fungi, actinomycetes, P- solubilizer and $\mathrm{N}$-fixer population in the soil. This is due 
to the increased organic carbon content upon application of FYM which acted as carbon and energy source for microbes and their quick build up in the soil. These findings are in conformity with the findings of Kiran et al., (2015).

Among the different levels of jeevamrutha, application of jeevamrutha at $1500 \mathrm{~L} \mathrm{ha}^{-1}$ recorded significantly higher bacteria, fungi, actinomycetes, $\mathrm{P}$-solubilizer and $\mathrm{N}$-fixer population followed by jeevamrutha at 1000 $\mathrm{L} \mathrm{ha}{ }^{-1}$ and lower microbial population was recorded with no jeevamrutha application. This might be due to presence of enormous amount of microbial load in jeevamrutha which multiplies in the soil and acts as a tonic to enhance the microbial activity in the soil. Use of handful of soil for jeevamrutha preparation serves as source of initial inoculum for the growth of bacteria, fungi, actinomycetes, $\mathrm{N}$ - fixers and P- solubilizers. Hence, more number of beneficial microorganisms were usually found in organic liquid manure formulations as was reported by Devakumar et al., (2014).

Table.1 Effect of FYM and jeevamrutha on bacteria, fungi and actinomycetes population in rhizophere soil after harvest of sunflower

\begin{tabular}{|c|c|c|c|}
\hline Treatment & $\begin{array}{c}\text { Bacteria } \\
\left(\text { No. } \times 10^{6} \mathrm{CFU} \mathrm{g}^{-1}\right)\end{array}$ & $\begin{array}{c}\text { Fungi } \\
\left(\text { No. } \times 10^{4} \mathrm{CFU} \mathrm{g}^{-1}\right)\end{array}$ & $\begin{array}{c}\text { Actinomycetes } \\
\left(\text { No. } \times 10^{3} \text { CFU g }{ }^{-1}\right)\end{array}$ \\
\hline \multicolumn{4}{|c|}{ FYM } \\
\hline $\mathbf{F}_{1}-100 \% \mathrm{~N}^{*}$ & 23.57 & 13.57 & 26.60 \\
\hline $\mathrm{F}_{2}-125 \% \mathrm{~N}^{*}$ & 26.74 & 15.14 & 32.38 \\
\hline $\mathbf{F}_{3}-150 \% \mathrm{~N}^{*}$ & 30.65 & 20.41 & 39.00 \\
\hline S.Em \pm & 0.67 & 0.38 & 0.72 \\
\hline C.D at $5 \%$ & 2.01 & 1.14 & 2.16 \\
\hline \multicolumn{4}{|c|}{ Jeevamrutha } \\
\hline $\mathbf{J}_{0}$ - Control & 21.76 & 12.29 & 23.00 \\
\hline $\mathrm{J}_{1}-1000$ litre $\mathbf{h a}^{-1}$ & 28.02 & 16.76 & 35.14 \\
\hline $\mathbf{J}_{2-} 1500$ litre ha $^{-1}$ & 31.18 & 20.07 & 39.84 \\
\hline S.Em \pm & 0.67 & 0.38 & 0.72 \\
\hline C.D at $5 \%$ & 2.01 & 1.14 & 2.16 \\
\hline \multicolumn{4}{|c|}{ FYM X Jeevamrutha } \\
\hline $\mathbf{F}_{\mathbf{1}} \mathbf{J}_{\mathbf{0}}$ & 20.77 & 10.89 & 22.09 \\
\hline $\mathbf{F}_{\mathbf{1}} \mathbf{J}_{1}$ & 23.74 & 14.78 & 26.20 \\
\hline $\mathbf{F}_{\mathbf{1}} \mathbf{J}_{2}$ & 26.20 & 15.04 & 31.51 \\
\hline $\mathbf{F}_{2} \mathbf{J}_{0}$ & 22.22 & 12.63 & 23.29 \\
\hline $\mathbf{F}_{\mathbf{2}} \mathbf{J}_{\mathbf{1}}$ & 28.33 & 15.95 & 34.36 \\
\hline $\mathbf{F}_{2} \mathbf{J}_{2}$ & 29.67 & 16.83 & 39.49 \\
\hline $\mathbf{F}_{\mathbf{3}} \mathbf{J}_{\mathbf{0}}$ & 22.29 & 13.35 & 23.62 \\
\hline $\mathbf{F}_{3} \mathbf{J}_{1}$ & 32.00 & 19.55 & 44.87 \\
\hline $\mathbf{F}_{3} \mathbf{J}_{2}$ & 37.67 & 28.33 & 48.50 \\
\hline S.Em \pm & 1.16 & 0.66 & 1.25 \\
\hline C.D at $5 \%$ & 3.48 & 1.97 & 3.74 \\
\hline
\end{tabular}

FYM: Farm yard manure, * Nitrogen equivalent, DAS: Days after sowing, NS: Non significant 
Table.2 Effect of FYM and jeevamrutha on P-solubilisers, N-fixers population\& dehydrogenase enzyme activity in rhizophere soil after harvest of sunflower

\begin{tabular}{|c|c|c|c|}
\hline Treatments & $\begin{array}{c}\text { P-solubilizer } \\
\left(\text { No. } \times 10^{5} \mathrm{CFU} \mathrm{g}^{-1}\right)\end{array}$ & $\begin{array}{c}\text { N-fixer } \\
\left(\text { No. } \times 10^{5} \mathrm{CFU} \mathrm{g}^{-1}\right)\end{array}$ & $\begin{array}{c}\text { Dehydrogenase activity } \\
\text { ( } \mu \mathrm{g} \text { TPF formed/g of soil/ day) }\end{array}$ \\
\hline \multicolumn{4}{|c|}{ FYM } \\
\hline $\mathrm{F} 1-100 \% \mathrm{~N}^{*}$ & 19.91 & 17.93 & 26.98 \\
\hline $\mathrm{F} 2-125 \% \mathrm{~N}^{*}$ & 26.23 & 19.83 & 32.74 \\
\hline F3- $150 \% \mathrm{~N}^{*}$ & 27.85 & 21.67 & 40.27 \\
\hline S.Em \pm & 0.80 & 0.76 & 1.27 \\
\hline C.D at $5 \%$ & 2.40 & 2.29 & 3.80 \\
\hline \multicolumn{4}{|c|}{ Jeevamrutha } \\
\hline J0- Control & 18.21 & 16.30 & 24.01 \\
\hline J1- 1000 litre ha-1 & 27.34 & 21.02 & 35.86 \\
\hline J2- 1500 litre ha- 1 & 28.44 & 22.10 & 40.12 \\
\hline S.Em \pm & 0.80 & 0.76 & 1.27 \\
\hline C.D at $5 \%$ & 2.40 & 2.29 & 3.80 \\
\hline \multicolumn{4}{|c|}{ FYM X Jeevamrutha } \\
\hline F1J0 & 8.20 & 15.48 & 21.65 \\
\hline F1J1 & 24.74 & 18.59 & 28.61 \\
\hline $\mathrm{F} 1 \mathrm{~J} 2$ & 26.78 & 19.71 & 30.68 \\
\hline $\mathrm{F} 2 \mathrm{~J} 0$ & 22.58 & 16.18 & 23.64 \\
\hline $\mathrm{F} 2 \mathrm{~J} 1$ & 27.67 & 21.21 & 35.03 \\
\hline $\mathrm{F} 2 \mathrm{~J} 2$ & 28.44 & 22.09 & 39.57 \\
\hline $\mathrm{F} 3 \mathrm{~J} 0$ & 23.84 & 17.25 & 26.75 \\
\hline F3J1 & 29.60 & 23.27 & 43.95 \\
\hline $\mathrm{F} 3 \mathrm{~J} 2$ & 30.10 & 24.50 & 50.11 \\
\hline S.Em \pm & 1.38 & 1.32 & 2.19 \\
\hline C.D at $5 \%$ & 4.15 & 3.89 & 6.46 \\
\hline
\end{tabular}

FYM: Farm yard manure, * Nitrogen equivalent, DAS: Days after sowing, NS: Non significant 
Table.3 Seed yield (kg/ha) and oil content of sunflower as influenced by different levels of FYM and jeevamrutha

\begin{tabular}{|c|c|c|}
\hline Treatment & Seed yield(kg/ha) & Oil content $(\%)$ \\
\hline \multicolumn{3}{|c|}{ FYM } \\
\hline$F_{1}-100 \% N^{*}$ & 1959 & 41.86 \\
\hline$F_{2}-125 \% N^{*}$ & 2168 & 42.10 \\
\hline $\mathrm{F}_{3}-150 \% \mathrm{~N}^{*}$ & 2335 & 42.45 \\
\hline S.Em \pm & 30.03 & 0.16 \\
\hline C.D at $5 \%$ & 90.03 & NS \\
\hline \multicolumn{3}{|c|}{ Jeevamrutha } \\
\hline $\mathbf{J}_{0^{-}}$- Control & 1886 & 41.99 \\
\hline $\mathrm{J}_{1^{-}} 1000$ litre $\mathrm{ha}^{-1}$ & 2227 & 42.14 \\
\hline$J_{2^{-}} 1500$ litre ha $^{-1}$ & 2349 & 42.27 \\
\hline S.Em \pm & 30.03 & 0.16 \\
\hline C.D at $5 \%$ & 90.03 & NS \\
\hline \multicolumn{3}{|c|}{ FYM X Jeevamrutha } \\
\hline $\mathbf{F}_{1} \mathbf{J}_{\mathbf{0}}$ & 1737 & 40.02 \\
\hline $\mathbf{F}_{\mathbf{1}} \mathbf{J}_{\mathbf{1}}$ & 2032 & 41.84 \\
\hline $\mathbf{F}_{\mathbf{1}} \mathbf{J}_{\mathbf{2}}$ & 2108 & 41.61 \\
\hline $\mathbf{F}_{2} \mathbf{J}_{\mathbf{0}}$ & 1894 & 41.92 \\
\hline $\mathbf{F}_{2} \mathbf{J}_{1}$ & 2243 & 41.99 \\
\hline $\mathbf{F}_{2} \mathbf{J}_{2}$ & 2367 & 42.01 \\
\hline $\mathbf{F}_{3} \mathbf{J}_{0}$ & 2028 & 41.85 \\
\hline $\mathbf{F}_{\mathbf{3}} \mathbf{J}_{\mathbf{1}}$ & 2405 & 42.06 \\
\hline $\mathbf{F}_{3} \mathbf{J}_{2}$ & 2573 & 42.89 \\
\hline S.Em \pm & 52.01 & 0.27 \\
\hline C.D at $5 \%$ & 156.03 & NS \\
\hline
\end{tabular}

FYM: Farm yard manure, ${ }^{*}$ Nitrogen equivalent, DAS: Days after sowing, NS: Non significant

\section{Dehydrogenase activity}

Application of FYM at 150 per cent $\mathrm{N}$ equivalent was recorded significantly higher dehydrogenase activity $(40.27 \mu \mathrm{g}$ TPF formed/ $\mathrm{g}$ of soil/ day) and whereas significantly decreased dehyrogenase activity was observed with FYM application at 100 per cent $\mathrm{N}$ equivalent (26.98 $\mu \mathrm{g}$ TPF formed/ $\mathrm{g}$ of soil/ day)at flowering stage of the crop growth (Table 2). Among the different levels of jeevamrutha, application of jeevamrutha at $1500 \mathrm{~L} \mathrm{ha}^{-1}$ recorded significantly higher dehydrogenase activity(40.12 $\mu \mathrm{g}$ TPF formed/ $\mathrm{g}$ of soil/ day) followed by jeevamrutha at
$1000 \mathrm{~L} \mathrm{ha}^{-1}$ (35.86 $\mu \mathrm{g}$ TPF formed/ $\mathrm{g}$ of soil/ day). Whereas significantly decreased dehyrogenase activity was observed with no jeevamrutha application (24.01 $\mu \mathrm{g}$ TPF formed/ $\mathrm{g}$ of soil/ day). Among the treatment combinations, integrated application of FYM at 150 per cent $\mathrm{N}$ equivalent and jeevamrutha at $1500 \mathrm{~L} \mathrm{ha}^{-1}$ recorded significantly higher dehydrogenase activity $(50.11 \mu \mathrm{g} \quad \mathrm{TPF}$ formed/ $g$ of soil/ day) which was on par with FYM at 150 per cent $\mathrm{N}$ equivalent and jeevamrutha at $1000 \mathrm{~L} \mathrm{ha}^{-1}(43.95 \mu \mathrm{g}$ TPF formed/ $g$ of soil/ day) and significantly decreased dehydrogenase activity was observed with FYM application at 100 per 
cent $\mathrm{N}$ equivalent and without jeevamrutha application (21.65 $\mu \mathrm{g}$ TPF formed/ $\mathrm{g}$ of soil/ day) at flowering stage of the crop growth (Table 2).

Increased soil organic matter status and microbial population known to stimulate the dehydrogenase activity in the soil. The increased dehydrogenase activity in the present investigation upon addition of FYM at different levels is due to increased microbial population. Tejada et al., (2010) recorded maximum dehydrogenase activity with 100 per cent substitution of RDN with FYM, vermicompost, poultry manure and biogas slurry and concluded that higher dehydrogenase enzyme activity in soil is due to greater labile fraction of organic matter in the soil and similar findings have been reported by Jaffar Basha et al., (2017).

Irrespective of jeevamrutha levels, FYM at $150 \% \mathrm{~N}$ equivalent recorded significantly higher seed yield (2335 $\mathrm{kg} \mathrm{ha}^{-1}$ ) (Table 3) which was an increase of 7.15 and 16.10 per cent over FYM at $125 \% \mathrm{~N}$ equivalent and FYM at $100 \% \mathrm{~N}$ equivalent, respectively and may be attributed to stimulation of activity of microorganisms and subsequent mineralization of nutrients and enhanced nutrient use efficiency that has helped to make the plant nutrients readily available to sunflower crop. Similarly, increase in seed yield of Sunflower in jeevamrutha at 15001 $\mathrm{ha}^{-1}$ could be due to better availability of nutrients throughout the crop growth and this has been evidenced by improved microbial activity in the soil (Table $1 \& 2$ ). These findings are in conformity with Manjunath et al., (2009), Ravi Kumar (2009), Guriqbalsingh et al., (2012). Beneficial effects of jeevamrutha due to huge quantity of microbial load and growth hormones leading to sustaining the availability and uptake of applied as well as native soil nutrients resulting in enhanced growth and yield of crops has been well documented by Sharma and Thomas (2010). Oil content of sunflower was non-significant.

Thus, it is evident that combined application of FYM and jeevamrutha resulted in higher microbial population which was due to the fact that FYM serves as a source of carbon for microbes and the liquid organic manure i.e. jeevamrutha contains higher number of bacteria, fungi, actinomycets, N-fixers and Psolubilizers. These organic manures not only supply the nutrients but it also serves as a source of organic carbon for the microbes, there by improves the microbial population in the soil which inturn helps to improves the mineralisation of nutrients in soil thus, fertility and productivity of the soil gets improved. Application of these organic sources like FYM and jeevamrutha would supplement the application of bio-fertilizers and these can be prepared easily by locally available materials by the farmers.

\section{References}

Allen, O.N., 1959, The isolation of Azotobacter species. In: Experiments in soil microbiology, Burgess Publishing Company, Minneapolis, 15-Minnesota, Pp.46- 47.

Devakumar, N., Shubha, S., Gouder, S. B. andRao, G. G. E., 2014, Microbial analytical studies of traditional organic preparations beejamrutha and jeevamrutha, Proc. Building Organic Bridges. $4^{\text {th }}$ ISOFAR Scientific Conference, Istanbul, Turkey, p. 639.

Devakumar. N., Rao, G. G. E., Shubha, S., Imrankhan, Nagaraj and Gowda, S. B., 2008, Activities of Organic farming research centre, Navile, Shimoga, Univ. Agril. Sci., Bengaluru, Karnataka, India.

Gomez, K. A. andGomez, A. A., 1984, Statistical procedures agricultural research, (2/e) an international rice 
research institute book, A Willey Inter Science Publication, John Willey and Sons, New York.

Guriqbal Singh, Sekhon, H. S. and Harpreeth K., 2012, Effect of farmyard manure, vermicompost and chemical nutrients on growth and yields of chickpea (Cicer arietinum L.). Int. J. Agric. Res., 7(2): 93-99.

Jackson, L. E., Bowler, T. M., Hodson, A. K. and Lazcano, C., 2012 Soil microbial and microbial rhizosphere processes to increase nitrogen availability and retention in agroecosystems. Curr.Opin. Environ. Sustain., 4, 517-522.

JaffarBasha, S., Basavarajappa, R., Geeta Shirnalli and Babalad, H. B. 2017, Soil microbial dynamics and enzyme activities as influenced by organic and inorganic nutrient management in vertisols under aerobic rice cultivation. J.env. Bio. 38(9): 131-138.

Kiran, SatyanarayanaRao, Vivekananda Reddy and Shubha, S., 2015, Effect of nutrient management practices through organics on soil biological properties in organic chickpea (Cicer arietinum L.) cultivation under rainfed condition. An Int. quarterly J. Environmental Sci. Vol
VII: 183-187.

Manjunatha, G. S., Upperi, S. N., Pujari, B. T., Yeledahalli, N. A. and Kuligoda, V. B., 2009, Effect of farm yard manure treated with jeevamrutha on yield attributes and economics of sunflower (Helianthus annuus L.). Karnataka J. Agric. Sci., 22 (1):342-348.

Ravi Kumar, H. S., 2009, Comparative performance of integrated organic nutrient supply systems on growth and yield of groundnut (Arachis hypogaea L.).M.Sc.(Agri.) Thesis, Univ. Agric. Sci., Bengaluru.

Sharma, V. andThomas, A., 2010, Response of blackgram (Phaseolus mungo L.) to nitrogen, zinc and farm yard manure. Legume Res., 33 (4):295-298.

Tejada, M., Gomez, I. H. Teresaand Garcia, C., 2010, Utilization of vermicompost in the soil restoration: effects on soil biological properties. Soil Sci. Soc. American J., 74, 525-532.

Tharmaraj, G. P., Suresh, R., Anandan, A. and Kolanjinathan, K., 2011, A Critical Review on Panchagavya - A Boon Plant Growth. Int J. Pharmaceutical \& Biological Archives, 2(6): 1611-1614.

\section{How to cite this article:}

Chaithra, M. and Sujith, G. M. 2020. Soil Microbial Dynamics and Enzyme activities as Influenced by Organic Nutrient Management in Sunflower (Helianthus annuus L.). Int.J.Curr.Microbiol.App.Sci. 9(08): 1087-1094. doi: https://doi.org/10.20546/ijcmas.2020.908.119 